\title{
Performance Audit: Applying the Principle of Effectiveness in a Case Study
}

\author{
Luiz Gilberto Monclaro Mury ${ }^{1,2}$ \\ ${ }^{1}$ Post-doctor in Economics at Federal University of RS, Porto Alegre, Brazil \\ ${ }^{2}$ Public Auditor at RS State Court of Accounts, Brazil \\ Correspondence: Luiz Gilberto Monclaro Mury, Public Auditor at RS State Court of Accounts, Brazil.
}

Received: December 6, 2019 Accepted: January 3, 2020 Available online: January 10, 2020

doi:10.11114/afa.v6i1.4682 URL: https://doi.org/10.11114/afa.v6i1.4682

\begin{abstract}
This article, based on a performance audit focused on the principle of effectiveness, aims at analyzing the impact resulting from the adoption of private textbooks for the primary school network of a municipality located in South of Brazil. For this, an assessment methodology known as difference-in-differences has been applied to data from the Brazilian Basic Education Assessment System, revealing the impact, on the municipality schools grades, for the use of textbook material other than those provided free of charge by the Federal government.
\end{abstract}

Keywords: performance audit, difference-in-differences, textbook material, principle of effectiveness

\section{Introduction}

The International Organization of Supreme Audit Institutions [INTOSAI ${ }^{1}$ ], which operates as an umbrella organization for the external government audit community, defines three main types of public-sector audit: Financial, Compliance and Performance audit.

To guide their concepts among the SAIs - Supreme Audit Institutions, INTOSAI elaborates its professional standards framework, the so called ISSAI ${ }^{2}$, which is structured in four levels. Level 1 (ISSAI 1) states the founding principles applicable to every public sector audit regardless form or context. Level 2 (ISSAI 10-99) establishes the prerequisites for the satisfactory functioning and professional conduct of SAIs, e.g., independence, transparency, accountability, ethics and quality control. Level 3 (ISSAI 100-999), presents the fundamental auditing principles for each type of auditing: Financial, Performance and Compliance. (Highlighted by the author) Finally, level 4 (ISSAI 1000-4999) translates the founding principles into more specific and detailed auditing guidelines. Regarding Performance audits, INTOSAI presents the following concept:

Performance audit focuses on whether interventions, programs and institutions are performing in accordance with the principles of economy, efficiency and effectiveness and whether there is room for improvement. Performance is examined against suitable criteria, and the causes of deviations from those criteria or other problems are analyzed. The aim is to answer key audit questions and to provide recommendations for improvement (ISSAI 300, p.2).

The effectiveness, which is the focus of the present paper, can be defined as the achievement of the desired results in the medium and long term. It refers to the relationship between the outcomes of an intervention or program, in terms of effects on the target population (observed impacts), and the intended objectives (expected impacts).

Surveys conducted in 2018 in Brazil and in several countries found that SAIs rarely undertake Performance Audits focusing on the principle of effectiveness (MURY, 2018, 2019). The reason seems to be the difficulty to measure the impact generated by a public policy, because to perform audits that focus on the economy and efficiency principles, one

\footnotetext{
${ }^{1}$ INTOSAI is a non-governmental organization established as a permanent institution with special consultative status with the Economic and Social Council (ECOSOC) of the United Nations. (See www.intosai.org).

${ }^{2}$ International Standards of Supreme Audit Institutions.
} 
needs to conduct a process evaluation ${ }^{3}$, while to audit the effectiveness principle it is necessary to undertake an impact assessment, which, according to Gertler et al. (2016, p. 328), has the following definition:

"An evaluation that makes a causal link (highlighted by the author) between a program or intervention and a set of outcomes. An impact evaluation answers the question: What is the impact (or causal effect) of a program on an outcome of interest?"

To be able to estimate the causal effect or impact of a public program on outcomes, any impact assessment must estimate the so-called counterfactual: that is, what would have been the outcome for program participants if they had not participated in the program. In practice, impact evaluation requires that evaluation team finds a comparison group (also known as control group) to estimate what happens to individuals who do not take part in the program and then make comparisons with the group that has participated in the program (also known as treatment group). In other words: it is to verify the occurrence of changes in the target population that could reasonably be attributed to the objectives of an evaluated program.

Process and impact evaluations also differ on the methodology applied. While the use of surveys, interviews, direct observation and descriptive statistics apply to process evaluation, according to Gertler et al. (2016, p. 8) every impact assessment method must address a cause-effect methodology.

\subsection{Hypothesis}

Given the context presented above, this article intends to answer the following question: is there a positive impact because of the adoption, by a Brazilian municipality ${ }^{4}$, of didactic textbooks for public primary schools other than those provided free of charge by the Federal government?

In order to examine the hypothesis, the remainder of this paper is divided into four sections including introduction and conclusion. Section two begins with a brief overview of the evaluated municipality, followed by a short context of the instructional material options for Brazilian primary schools and an introduction to the Brazilian basic education assessment system. Section three discusses the fieldwork, divided into applied methodology, data analysis and data measurement. Finally, section four is reserved for the article's findings.

\section{Primary School: Brief Overview in Brazil and Current Figures of the Brazilian Municipality}

According to the 1988 Brazilian Constitution, the State's duty to education should be fulfilled by ensuring free compulsory basic education from 4 to 17 years old, including free provision for all those who did not have access at their correct age (Art. 208). Private institutions are permitted, provided some conditions, including compliance with the general norms of national education (Art. 209). The Federal Government, States, the Federal District and the municipalities will collaboratively organize their educational systems. The Central government organizes the federal educational system and finances the federal public education institutions, among other functions. Municipalities primarily offer primary and early childhood education, while the States and the Federal District act primarily in fundamental and secondary education. In the educational systems organization, all public levels will define forms of collaboration in order to ensure the universalization of compulsory education (Art. 211). Finally, it is important to mention that the Federal government must annually apply, to the maintenance and development of education, no less than eighteen per cent of the revenue resulting from all taxes, while the States, the Federal District and the municipalities twenty-five per cent (Art. 212).

Data from the Brazilian Institute of Geography and Statistics - IBGE ${ }^{5}$ (http://cidades.ibge.gov.br) informs that the municipality investigated in this paper has a population of approximately 280 thousand inhabitants and with a per capita income of about US\$10.3 Thousand per year ${ }^{6}$ (estimated for 2015).

As per the Rio Grande do Sul State Court of Accounts - TCE/RS Open Data (http://dados.tce.rs.gov.br/), local government revenue totalized US\$ 207 Million in 2018, of which US\$ 44 Million from local tax collecting, and US\$ 163 Million from State and Federal transfers. With regards to education spending, in 2018 it achieved US\$ 57 Million, of which US\$ 36 Million for the primary schools. Table 1 shows the local educational figures.

\footnotetext{
${ }^{3}$ Focus on how a program is implemented and operates, assessing whether it conforms to its original design and documenting its development and operation. Gertler et al. (2016, p. 16)

${ }^{4}$ The municipality will not be disclosed, as the subject addressed here is part of a performance audit still in progress.

${ }^{5}$ IBGE is the main provider of data and information about Brazil. Such information meets the demands of several types of segments of civil society, as well as the bodies at the federal, state and municipal level. Source: https://www.ibge.gov.br/en/institutional/the-ibge.html

${ }^{6}$ Source: RS Economics and Statistics Foundation. https://www.fee.rs.gov.br/indicadores/pib-rs/municipal/destaques/
} 
Table 1. Municipality educational structure

\begin{tabular}{|c|c|c|}
\hline 2018 & Primary & High School \\
\hline Nr of enrolments & 34.882 & 8.870 \\
\hline Nr of teachers & 1.611 & 535 \\
\hline Nr of schools ${ }^{7}$ & 99 & 27 \\
\hline
\end{tabular}

Source: https://cidades.ibge.gov.br/brasil/

Next subsections present the teaching material options for Brazilian municipalities, as well as the official assessment system for the Brazilian basic education, which will be employed for the impact assessment.

\subsection{Textbook Material for Primary Schools}

According to the Brazilian Ministry of Education website, the Federal Government provides pedagogical support through the National Program of Book and Teaching Material (PNLD), which distributes, on regular basis and free of charge, didactic, pedagogical and literary works, among others to support educational practice to public schools of federal, state, municipal, and district networks, as well as nonprofit community-based, religious, or philanthropic early childhood institutions.

PNLD is considered the oldest program to distribute didactic books to Brazilian public schools. Until 1995, the distribution of books was limited to a few years and not on regular basis. Nowadays it serves millions of students from public schools, from the first primary to high school. Table 2 presents the PNLD 2019 figures.

Table 2. PNLD in figures 2019

\begin{tabular}{|c|c|c|c|c|}
\hline Teaching Step & $\begin{array}{l}\text { Benefited } \\
\text { Schools }\end{array}$ & $\begin{array}{l}\text { Benefited } \\
\text { Students }\end{array}$ & Number of books & $\begin{array}{c}\text { Acquisition Value in } \\
\text { US\$ }\end{array}$ \\
\hline Child education & 74.409 & 5.448 .222 & 646.795 & 2.500 .000 \\
\hline Early Years of Primary School ( $1^{\text {st }}$ to $4^{\text {th }}$ year $)$ & 92.467 & 12.189 .389 & 80.092 .370 & 154.000 .000 \\
\hline Final Years of Primary School $\left(5^{\text {th }}\right.$ to $9^{\text {th }}$ year $)$ & 48.529 & 10.578 .243 & 24.523 .891 & 56.000 .000 \\
\hline High school & 20.229 & 6.962 .045 & 20.835 .977 & 63.000 .000 \\
\hline Total & 147.857 & 35.177 .899 & 126.099 .033 & 275.500 .000 \\
\hline
\end{tabular}

Source: https://www.fnde.gov.br/index.php/programas/programas-do-livro/pnld/dados-estatisticos

Aside from PNLD, there are several publishers that provide textbooks for the private school network, and for public schools that do not wish to utilize the free material distributed by the Federal government .

One of these publishers supplies the municipality subject of this paper with:

“... a complete educational system of solutions for the public educational network: Integrated Textbook, Pedagogical Advisory, internet learning portal and own assessment system. It was developed to enhance the quality (highlighted by the author) of teaching in municipality schools, since the contents of one year continue with those of the previous period, ensuring a progressive, articulated and interdisciplinary learning...."

As they have the same objective as the National public program, the aim of this paper is to measure if the use of the private educational materials improved the quality of education offered in the given municipality.

\subsection{Brazilian Basic Education Assessment System - SAEB}

The SAEB consists of a set of large-scale external evaluations developed by the Ministry of Education. Data are available by school to everyone and are intended to assess the quality of education offered by the Brazilian educational system. This evaluation system was established in 2005 and is applied every two years through cognitive tests and questionnaires for specific stages of basic education. The evidence produced by SAEB allows a broad diagnosis of the basic education offered in the country, as well as the elaboration, monitoring and improvement of the educational policies. In the 2017 edition, the latest with available data, more than 5.4 million students took part in the assessment from about 73,000 private and public schools throughout Brazil. In the tests applied in the fifth and ninth grade of primary school, students answered questions of Portuguese language focused on reading, and mathematics focused on problem solving (Source: http://portal.mec.gov.br/prova-brasil, accessed on $19^{\text {th }}$ Nov., 2019). For the purpose of this

\footnotetext{
${ }^{7}$ Part of these schools belong to the Rio Grande do Sul State, and part to the municipality.
} 
paper, the school grade taken for research is the average proficiency of their 5th grade students in Portuguese language and mathematics, standardized to an indicator between 0 and 10 available in the SAEB website.

\section{Fieldwork Research - Methodology, Data Collection and Data Measurement}

This session is reserved for applying performance auditing concepts focusing on the effectiveness of public expenditure in a case study. It begins with the presentation of a tool for quantitative data analysis, followed by the methodology for data collection and data measurement.

\subsection{Methodology}

One of the most popular methods to estimate the effect of a policy change is the so-called difference in differences (DD). It is a statistical technique derived from the multiple regression analyses ${ }^{8}$ used in econometrics and quantitative research in the social sciences that attempts to mimic an experimental research design using observational study data. DD estimator is used when there is available data before and after treatment, and when the separation between treatment and control groups has not been performed randomly. The difference in average of the products before and after the intervention is calculated for each group: treated and control. Finally the difference between these two differences is the estimated impact. Table 3 presents it schematically.

Table 3. Difference in differences methodology

Before After Difference

\begin{tabular}{cccc} 
Control & A & B & B-A \\
\hline Treatment & C & D & D-C \\
\hline Difference & C-A & D-B & (B-A) - (D-C) \\
\hline
\end{tabular}

Source: Adapted from Fundação Itau Social

- A-B and C-D represent the extent to which the control and treatment groups changed, respectively, between the period before and after the intervention;

- As, by hypothesis, the control group was not impacted by the project, so the difference (B-A) is a result of the other factors affecting the impact indicator;

- Therefore, by subtracting B-A from D-C, it is expected that these other factors are canceling each other out and, consequently, only the effect of the project remains.

\subsection{Data collection}

To perform a regression based on the DD methodology, SAEB average grades were retrieved from a sample of primary schools of the target municipality, before and after the adoption of the private textbooks.

The private publisher signed a contract with the target municipality in December 2013 to provide its teaching system. The purpose of this contract, which has being renewed every year since then, is: "the acquisition of integrated textbooks from the educational system $\mathrm{X}$, which aims to serve students from grades 1 to 5 of the municipal school methods and improvement of school performance" (highlighted by the author).

As per ISSAI 300, the principle of effectiveness concerns meeting the objectives set and achieving the intended results. Based on this concept, a performance audit was undertaken to evaluate if the schools performance have improved after 4 years using private didactic material.

To establish the schools sample, criterion was to select, between all primary schools in the municipality, only the ones that had at least 4 SAEB average grades among the 7 SAEB tests from 2005 to 2017. In total, 57 schools were considered, comprising 370 grades in the $5^{\text {th }}$ year (when students take the SAEB test subject to the paper analysis). From 2014 on, after the private teaching method program began, the 38 municipal schools that adopted these didactic books turned into the so-called treatment group. With regards to the control group, if all primary schools in the municipality had adopted the private teaching method, it would be very difficult to build a reliable control group; hence,

\footnotetext{
${ }^{8}$ In statistics, regression is a technique that allows quantifying the relationship between the values of a dependent variable (impact indicator) and the values of specific independent variables (explanatory variables).
} 
no impact assessment could have been performed. Instead, 3 from the 41 municipal primary schools, and all 16 primary schools run by the Rio Grande do Sul State did not use the learning material from the private publisher during the research period; therefore, they are the control group. It is important to mention that in both groups: treatment and control, schools vary in size and in number of students; therefore, these characteristics do not interfere in the analysis. Table 4 shows data ${ }^{9}$ from all schools taken for the difference in differences calculation.

Table 4. SAEB school grades

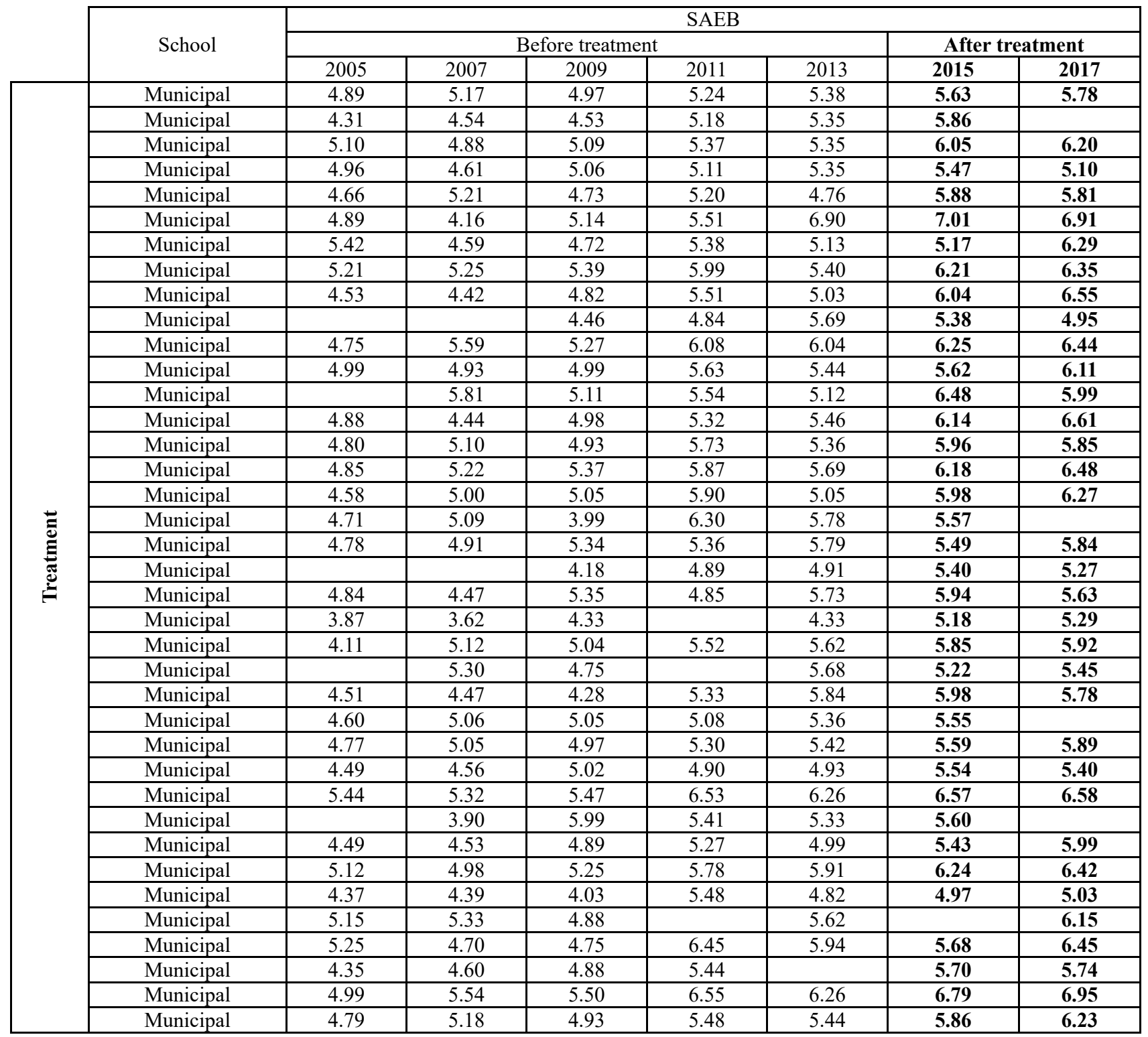

\footnotetext{
${ }^{9}$ The average standardized grade was taken from the SAEB tests performed in the years 2005, 2007, 2009, 2011, 2013, 2015 and 2017 (Source: http://idebescola.inep.gov.br/ideb/consulta-publica).
} 


\begin{tabular}{|c|c|c|c|c|c|c|c|c|}
\hline & \multirow{3}{*}{ School } & \multicolumn{7}{|c|}{ SAEB } \\
\hline & & \multicolumn{5}{|c|}{ Before treatment } & \multicolumn{2}{|c|}{ After treatment } \\
\hline & & 2005 & 2007 & 2009 & 2011 & 2013 & 2015 & 2017 \\
\hline \multirow{19}{*}{$\begin{array}{l}\overline{0} \\
\stackrel{\Xi}{0} \\
0\end{array}$} & Municipal & 4.97 & 5.01 & 5.57 & 6.00 & & 6.20 & \\
\hline & Municipal & 4.83 & 4.99 & 5.06 & 4.99 & 5.37 & 5.75 & 5.86 \\
\hline & Municipal & 4.12 & 4.26 & 5.39 & 4.63 & 5.26 & & 6.25 \\
\hline & State & 5.42 & 5.23 & 4.51 & 6.25 & & 6.43 & 6.47 \\
\hline & State & 5.42 & 4.97 & 5.45 & 5.38 & 5.79 & 5.98 & 6.99 \\
\hline & State & 4.49 & 4.82 & 5.29 & 4.96 & 5.49 & 5.41 & 6.18 \\
\hline & State & 4.98 & 5.13 & 4.93 & 5.57 & 5.87 & 6.25 & 6.59 \\
\hline & State & 4.90 & 5.44 & 5.21 & 6.12 & & 5.82 & 6.65 \\
\hline & State & & & 5.58 & & 5.80 & 6.48 & 6.56 \\
\hline & State & 4.88 & 4.87 & 5.49 & 6.32 & 5.95 & 5.82 & 5.57 \\
\hline & State & 5.15 & 5.36 & 5.18 & 5.90 & 5.97 & 5.72 & 5.61 \\
\hline & State & 5.05 & 5.23 & 5.74 & 5.70 & 5.84 & 5.71 & 6.09 \\
\hline & State & 5.19 & 4.87 & 4.69 & 4.99 & 5.47 & 5.86 & 6.20 \\
\hline & State & 5.02 & 5.66 & 5.66 & 6.02 & 5.86 & 5.73 & 6.41 \\
\hline & State & 5.44 & 4.43 & 5.71 & 6.26 & 6.16 & 6.21 & 6.33 \\
\hline & State & 4.60 & 4.86 & 4.76 & 5.94 & 5.83 & 5.79 & 6.35 \\
\hline & State & & & 5.26 & 5.36 & 5.24 & 5.50 & \\
\hline & State & & & 4.57 & 4.34 & 4.95 & 4.90 & 5.67 \\
\hline & State & 4.80 & 5.20 & 5.08 & 5.78 & 5.54 & 6.45 & 6.33 \\
\hline
\end{tabular}

Source: http://idebescola.inep.gov.br/ideb/consulta-publica

\subsection{Data Measurement}

In order to measure the impact of the private teaching material on the school average grades by using the SAEB tests, this paper carried out the difference in differences technique using the Microsoft Excel software. The difference-indifferences calculation, as mentioned before, is a variation of the multiple regression analysis. What differs is that DD has a so called baseline, that is, there is information from the treatment and control groups before and after the treatment (in this case, the adoption of the private textbooks from 2014 on for some of the schools in the target municipality). For the purpose of this paper, the DD calculation presented here is a simplified version; the formal version, as a supplementary material, is in the Appendix A.

The difference-in-differences methodology begins with the scheme presented on Table 3, which is filled with the means of the data from Table 4 . Result is shown on Table 5.

Table 5. Average values from the 57 schools

\begin{tabular}{cccc}
\hline & Before & After & Difference \\
\hline Control & 5,2896 & 6,0606 & 0,7709 \\
\hline Treatment & 5,1159 & 5,9037 & 0,7877 \\
\hline Difference & $-0,1737$ & $-0,1569$ & $-0,0168$ \\
\hline
\end{tabular}

Source: Adapted from the SAEB grades

The result of the differences, - 0.0168 , means that there is a negative impact on the SAEB average school grades by adopting textbook material other than the one provided by the Federal Government.

\section{Findings}

Applying an impact assessment technique called difference-in-differences revealed that in the target municipality, schools using the private publisher teaching methods have, in average, a grade 0.0168 points lower after 4 years of the program, compared to public schools that kept using the public textbooks provided by the Federal Government.

The decision to adopt private teaching materials is up to the elected municipal government; however, they must be accountable to society about their choices. In this sense, a performance audit focusing on the principle of effectiveness helped to assess whether the choice made has achieved its objectives, since the municipality in question has unmet demands in the area of basic education (nursery places, for example), and resources are limited. 
According to public information retrieved from Licitacon Cidada $o^{10}$ system, the cost of the private material during the analyzed period - 2014 to 2017 - is around US\$ 4 million (US\$ 1 million per year), that is: a negative impact in the SAEB test of 0.0168 points for the money invested by the municipality.

The following Graphs allow a better visualization of the grades impact along the years. Graph 1 shows that the average grades of the treatment group have a good evolution along the years/SAEB tests. However, the control group presents similar evolution, which means that there is no improvement due to the adoption of the textbook material provided by the private publisher.

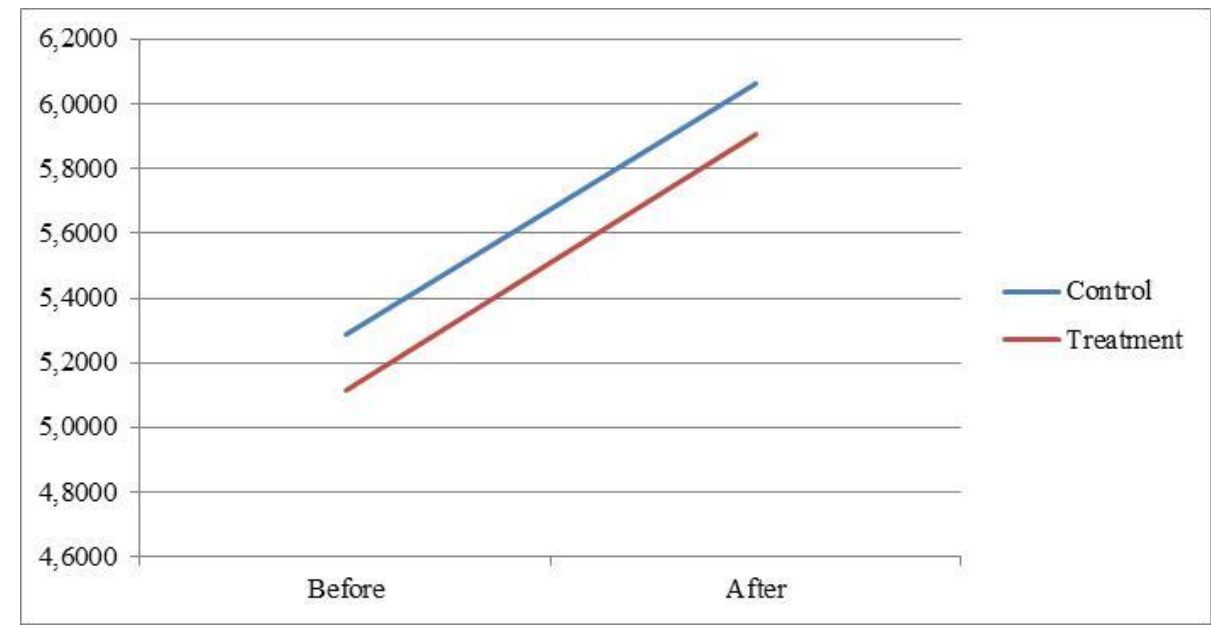

Graph 1. SAEB School grades

Source: Data elaborated from selected SAEB school grades

Graph 2 shows the evolution of the average grades along the years. It is possible to see that the treatment group presents a higher evolution between the SAEB tests of 2013 and 2015. Nevertheless, this is not maintained between 2015 and 2017; consequently, there is no positive impact by adopting the private teaching material.



Graph 2. SAEB School grades along the years

Source: Data elaborated from selected SAEB school grades

\footnotetext{
${ }^{10}$ LicitaCon is a web-based system developed by the Court of Auditors of RS to control and monitor the bids and administrative contracts signed by all State and municipal agencies of the Rio Grande do Sul state. The Citizen version, accessed for this paper, is available to anyone. (Source: http://www1.tce.rs.gov.br/aplicprod/f?p=50500:1)
} 


\section{Conclusions}

This article has analyzed the impact resulted for the adoption of private textbooks by the public school network of a Brazilian municipality. It is based on a performance audit focused on the principle of effectiveness that applied an assessment technique called difference-in-differences to data from the Brazilian Basic Education Assessment System. The result of the evaluation revealed that there was a negative impact of 0.0168 points on the average primary school grades, although the teaching material cost over US\$ 1 million per year for the municipality.

Surveys conducted in 2018 in Brazil and abroad found that Supreme Audit Institutions rarely undertake Performance Audits focusing on the principle of effectiveness. Hopefully, with the presentation of this paper, audits that evaluate the impacts on the population resulting from the use of public money can become more frequent.

\section{References}

Fundação Itaú Social. (2015). Avaliação Econômica de Projetos Sociais. Curso de Gestores, São Paulo: Fundação Itaú Social.

Gertler, P. J., Martinez, S., Premand, P., Rawlings, L. B., \& Vermeersch, C. M. (2016). Impact evaluation in practice. The World Bank. https://doi.org/10.1596/978-1-4648-0779-4

International Standards of Supreme Audit Institutions - ISSAI 300. Fundamental Principles of Performance Auditing. Retrieved from https://www.intosai.org/fileadmin/downloads/documents/open_access/ISSAI_100_ISSAI_400/issai_300/issai_30 0_en.pdf

Mury, L. (2018) Performance Audits Focused on the Principle of Effectiveness: An Overview of Public Audit Agencies. https://doi.org/10.11114/afa.v4i2.3488

Mury, L. (2019) Auditorias Operacionais com Foco no Princípio da Efetividade: Breve Panorama nos Tribunais de Contas do Brasil. Retrieved from https://revista.tcu.gov.br/ojs/index.php/RTCU/issue/view/87

Tribunal de Contas da União - TCU (2010). Manual de Auditoria Operacional. 3. ed. Brasília: TCU, Secretaria de Fiscalização e Avaliação de Programas de Governo (Seprog), 71 p. 


\section{Appendix A}

Difference-in-differences calculation using MS Excel requires the Data Analysis Module - Regression. For this, it is necessary to prepare a 4-column spreadsheet. The first column displays all SAEB grades stacked by school (370 in total); the second one shows the treatment condition as a variable ${ }^{11}: 1$ for treatment and 0 for non-treatment (control). The third column displays the time also as a dummy variable: 1 for after treatment and 0 for before treatment. Finally, the fourth column $\left(\mathrm{D}_{1} \mathrm{X}_{2}\right)$ results from the multiplication of the second and third columns. Table 6 displays how the spreadsheet looks.

Table 6. Difference-in-difference for the SAEB school grades

\begin{tabular}{|c|c|c|c|}
\hline $\begin{array}{l}\text { SAEB } \\
\text { grades }\end{array}$ & $\begin{array}{c}\text { Dummy for } \\
\text { treatment } \\
\left(D_{1}\right)\end{array}$ & $\begin{array}{c}\text { Dummy for } \\
\text { time }\left(D_{2}\right)\end{array}$ & $D_{1} \times D_{2}$ \\
\hline 4.89 & 1 & 0 & 0 \\
\hline 4.31 & 1 & 0 & 0 \\
\hline
\end{tabular}

\begin{tabular}{|l|l|l|l|}
\hline 6.95 & 1 & 1 & 1 \\
\hline 6.23 & 1 & 1 & 1 \\
\hline 5.86 & 0 & 1 & 0 \\
\hline 6.25 & 0 & 1 & 0 \\
\hline 6.18 & 0 & 1 & 0 \\
\hline
\end{tabular}

Source: Data elaborated from selected SAEB school grades

After processing the spreadsheet with MS Excel Data Analysis module - Regression, below is the Summary Output:

\begin{tabular}{lr}
\hline \multicolumn{2}{c}{ Regression Statistics } \\
\hline Multiple R & 0.58122 \\
R Square & 0.33781 \\
Adjusted R Square & 0.33239 \\
Standard Error & 0.51102 \\
Observations & 370 \\
\hline
\end{tabular}

\begin{tabular}{|c|c|c|c|c|c|c|}
\hline & $d f$ & $S S$ & $M S$ & $F$ & Significance $F$ & \\
\hline Regression & 3 & 48.75893 & 16.25298 & 62.23815 & 0.00000 & \\
\hline Residual & 395 & 95.57785 & 0.26114 & & & \\
\hline Total & 398 & 144.33677 & & & & \\
\hline & Coefficients & Standard error & $t$ Stat & $P$-value & Lower 95\% & Upper 95\% \\
\hline Intercept & 5.28965 & 0.05543 & 95.43289 & 0.00000 & 5.18065 & 5.39864 \\
\hline Dummy for treatment (D1) & -0.17373 & 0.06731 & -2.58083 & 0.01025 & -0.30610 & -0.04135 \\
\hline Dummy for time (D2) & 0.77092 & 0.10263 & 7.51150 & 0.00000 & 0.56910 & 0.97275 \\
\hline $\mathrm{D} 1 \mathrm{X} \mathrm{D} 2$ & 0.01682 & 0.12518 & 0.13433 & 0.89321 & -0.22935 & 0.26298 \\
\hline
\end{tabular}

Regression formula: SAEB $=-0.17373$ Treatment +0.77092 Time + 0.01682Impact +5.28965

As the variable D1 x D2 represents the impact, it is the focus of the following analysis.

\begin{tabular}{|c|c|l|}
\hline Output & Value & \multicolumn{1}{c|}{ Explanation } \\
\hline Coefficient & 0.01682 & $\begin{array}{l}\text { It means that, thanks to the private textbook program, the municipal schools presented, in average, } \\
\text { a decrease of } 0.01682 \text { points in the SAEB tests after 4 years. }\end{array}$ \\
\hline P-value & 0.89321 & $\begin{array}{l}\text { In order to determine if the coefficients influence the average school grades, the 1 - P-value should } \\
\text { be at least 0.95 (95\%). However, in this case the result is 10.7\%. showing that the coefficient does } \\
\text { not influence the average grades. }\end{array}$ \\
\hline $\begin{array}{c}\text { Confidence } \\
\text { interval } \\
(95 \%)\end{array}$ & 0.22935 & $\begin{array}{l}\text { As the interval contains the 0 value, with 95\% confidence we cannot reject the possibility that the } \\
\text { impact is zero. }\end{array}$ \\
\hline
\end{tabular}

${ }^{11}$ This type of indicative and binary variable is called dummy. It assumes only the values 0 or 1. 


\section{Appendix B (Executive summary for Portuguese readers)}

\section{Auditoria Operacional: Aplicando o princípio da efetividade em um estudo de caso.}

Este artigo, baseado em uma auditoria operacional focada no princípio da efetividade, tem como objetivo analisar o impacto resultante da adoção de livros privados pelas escolas primárias de um município localizado no sul do Brasil. Para tanto, uma metodologia de avaliação conhecida como diferença em diferenças foi aplicada aos dados do Sistema de Avaliação da Educação Básica - SAEB, revelando o impacto, nas notas médias das escolas municipais, pelo uso de material didático que não o fornecido gratuitamente pelo governo federal.

\section{Introdução}

A Organização Internacional das Instituições Superiores de Auditoria [INTOSAI ${ }^{12}$ ] define três tipos principais de auditoria do setor público: financeira, de conformidade e de desempenho.

Para orientar seus conceitos entre as denominadas ISA - Instituições Superiores de Auditoria, a INTOSAI define em quatro níveis sua estrutura de padrão profissional, as denominadas ISSAI ${ }^{13}$. O Nível 1 (ISSAI 1) declara os princípios fundamentais aplicáveis a todas as auditorias do setor público, independentemente de sua forma ou contexto. O Nível 2 (ISSAI 10-99) estabelece os pré-requisitos para o funcionamento satisfatório e a conduta profissional das ISA, por exemplo, independência, transparência, responsabilidade, ética e controle de qualidade. O Nível 3 (ISSAI 100-999), por sua vez, apresenta os princípios fundamentais para cada tipo de auditoria: de Desempenho, de Conformidade e Financeira. Finalmente, o nível 4 (ISSAI 1000-4999) traduz os princípios básicos em diretrizes de auditoria mais específicas e detalhadas.

Em relação às auditorias de desempenho, a INTOSAI apresenta o seguinte conceito:

A auditoria de desempenho concentra-se em saber se as intervenções, programas e instituições estão sendo executadas de acordo com os princípios de economia, eficiência e efetividade e se há espaço para melhorias. O desempenho é examinado de acordo com critérios adequados e as causas dos desvios desses critérios ou outros problemas são analisados. O objetivo é responder às principais perguntas de auditoria e fornecer recomendações para melhorias (ISSAI 300, p.2).

A efetividade, que é o foco do presente trabalho, pode ser definida como a obtenção de resultados desejados a médio- e longo prazos. Refere-se à relação entre os resultados de uma intervenção ou programa, em termos de efeitos na população-alvo (impactos observados) e dos objetivos pretendidos (impactos esperados).

Pesquisas realizadas em 2018 no Brasil e em vários países revelaram que as Instituições Superiores de Auditoria - ISA raramente realizam Auditorias de Desempenho com foco no princípio da efetividade (MURY, 2018, 2019). A razão parece ser a dificuldade de auditar o impacto gerado por um projeto ou programa de governo, já que para realizar auditorias com foco nos princípios de economicidade e eficiência realiza-se uma avaliação de processos ${ }^{14}$, enquanto que para auditar o princípio da efetividade é necessário desenvolver uma avaliação de impacto, a qual, segundo Gertler et al. (2016, p. 328), possui a seguinte definição:

"Avaliação que faz um nexo de causalidade (destacado pelo autor) entre um programa ou intervenção e um conjunto de resultados. Uma avaliação de impacto responde à pergunta: qual é o impacto (ou efeito causal) de um programa em um resultado de interesse?"

Para poder estimar o efeito causal ou o impacto de um programa sobre os resultados, qualquer avaliação de impacto deve estimar o chamado contrafactual: ou seja, qual teria sido o resultado para os participantes do programa se eles não tivessem participado do mesmo. Na prática, a avaliação de impacto exige que a equipe de avaliação encontre um grupo de comparação (também conhecido como grupo de controle) para estimar o que acontece com indivíduos semelhantes que não participam do programa e, em seguida, faça comparações com o grupo que participou do programa (também conhecido como grupo de tratamento). Em outras palavras: trata-se de verificar a ocorrência de mudanças na populaçãoalvo que possam ser razoavelmente atribuídas aos objetivos de um programa avaliado.

As avaliações de processos e de impactos também diferem na metodologia aplicada. Enquanto o uso de pesquisas, entrevistas, observação direta e estatística descritiva se aplicam à avaliação de processos, de acordo com Gertler et al. (2016, p. 8) todo método de avaliação de impacto deve abordar uma metodologia de causa-efeito.

\footnotetext{
${ }^{12}$ A INTOSAI é uma organização não governamental estabelecida como uma instituição permanente das Nações Unidas, e com status consultivo especial junto ao Conselho Econômico e Social (ECOSOC). (Acesse www.intosai.org).

${ }^{13}$ Normas internacionais das instituições supremas de auditoria.

${ }^{14}$ Concentra-se em como um programa é implementado e opera, avaliando se ele está em conformidade com seu design original e documentando seu desenvolvimento e operação. Gertler et al. (2016, p. 16)
} 


\subsection{Hipótese}

Dado o contexto apresentado acima, este artigo visa responder à seguinte pergunta: houve impacto positivo nas notas da Prova Brasil devido à adoção, por um município brasileiro ${ }^{15}$, de materiais didáticos que não os fornecidos gratuitamente pelo governo federal através do Programa Nacional do Livro Didático?

Para examinar a hipótese, o restante deste artigo está dividido em quatro seções, além da introdução e conclusão. A seção dois começa com uma visão geral e dimensão da estrutura da rede de escolas secundárias no município avaliado, seguido por um breve contexto das opções de material instrucional para escolas primárias brasileiras e introdução ao sistema brasileiro de avaliação da educação básica. A seção três discute o trabalho de campo, dividido em metodologia aplicada, análise e medição de dados. Finalmente, a seção quatro é reservada às constatações do artigo.

\section{Ensino Fundamental: Breve visão geral no Brasil e contexto atual no município brasileiro}

De acordo com a Constituição Brasileira de 1988, o dever do Estado com a educação deve ser cumprido, garantindo a educação básica obrigatória gratuita de 4 a 17 anos, incluindo a provisão gratuita para todos aqueles que não tiveram acesso na idade correta (Art. 208). São permitidas instituições privadas, desde que algumas condições sejam atendidas, incluindo o cumprimento das normas gerais da educação nacional (Art. 209). O governo federal, os estados, o distrito federal e os municípios organizarão colaborativamente seus sistemas educacionais. O governo federal organiza o sistema educacional em nível nacional e financia as instituições públicas federais de educação, entre outras funções. Os municípios oferecem principalmente educação infantil e fundamental, enquanto os Estados e o Distrito Federal atuam principalmente no ensino fundamental e médio. $\mathrm{Na}$ organização dos sistemas educacionais, todos os níveis públicos definirão formas de colaboração a fim de garantir a universalização do ensino obrigatório (Art. 211). Finalmente, é importante mencionar que o governo federal deve aplicar anualmente, para manutenção e desenvolvimento da educação, ao menos dezoito por cento da receita resultante de todos os impostos, enquanto os Estados, o Distrito Federal e os municípios, vinte e cinco por cento (art. 212).

Dados do Instituto Brasileiro de Geografia e Estatística - IBGE ${ }^{16}$ (http://cidades.ibge.gov.br) informam que o município investigado neste trabalho possui uma população de aproximadamente 280 mil habitantes e com uma renda per capita de cerca de R\$ 35 mil por ano ${ }^{17}$ (estimado para 2015). De acordo com o Tribunal de Contas do Estado do Rio Grande do Sul - TCE / RS Dados Abertos (http://dados.tce.rs.gov.br/), a receita do governo local totalizou R $\$ 750$ milhões em 2018, dos quais R\$ 160 Milhões por meio da arrecadação de impostos locais e $\mathrm{R} \$ 590$ milhões via transferências estaduais e federais. Gastos com educação alcançaram R \$ 210 milhões em 2018, dos quais R \$ 134 milhões para as escolas primárias. Com relação à estrutura educacional, a Tabela 1 mostra os números do município ${ }^{18}$ (Tabela se encontra no corpo do texto em inglês).

As próximas subseções apresentam as opções de material didático para os municípios brasileiros, bem como o sistema oficial de avaliação da educação básica brasileira, que será empregado na avaliação de impacto.

\subsection{Material didático para escolas primárias}

De acordo com o site do Ministério da Educação do Brasil, o Governo Federal presta apoio pedagógico por meio do Programa Nacional de Livros e Material Didático (PNLD), que distribui regularmente e de forma gratuita, obras didáticas, pedagógicas e literárias, entre outros, para apoiar prática educacional a escolas públicas de redes federais, estaduais, municipais e distritais, bem como a instituições comunitárias sem fins lucrativos, religiosas ou filantrópicas da primeira infância.

O PNLD é considerado o programa mais antigo de distribuição de livros didáticos para escolas públicas brasileiras. Até 1995, a distribuição de livros era limitada a algumas séries e não de forma regular. Atualmente, atende a milhões de alunos de escolas públicas, do primeiro ano do ensino fundamental ao ensino médio. A Tabela 2 apresenta os números do Programa Nacional do Livro Didático em 2019. Além do PNLD existem várias editoras que fornecem livros didáticos para a rede de escolas particulares, e também para escolas públicas que não desejem o material distribuído gratuitamente pelo governo Federal. Uma dessas editoras fornece ao município em questão:

\footnotetext{
${ }^{15} \mathrm{O}$ município não será divulgado, pois o assunto aqui abordado faz parte de uma auditoria de desempenho ainda em andamento.

${ }^{16}$ O IBGE é o principal provedor de dados e informações sobre o Brasil. Essas informações atendem às demandas de diversos tipos de segmentos da sociedade civil, bem como dos órgãos federal, estadual e municipal. Fonte: https://www.ibge.gov.br/en/institutional/the-ibge.html

${ }^{17}$ Fonte: Fundação de Economia e Estatística do RS.https://www.fee.rs.gov.br/indicadores/pib-rs/municipal/destaques/

${ }^{18}$ Parte das escolas pertence ao estado do Rio Grande do Sul e parte ao município.
} 
“... Um sistema educacional completo de soluções para a rede pública de ensino: Livro Integrado, Assessoria Pedagógica, portal de aprendizado na Internet (...) Foi desenvolvido para aprimorar a qualidade (destacada pelo autor) do ensino nas escolas municipais, uma vez que os conteúdos de um ano continuam com os do periodo anterior, garantindo um aprendizado progressivo, articulado $e$ interdisciplinar.... "

Como a editora tem o mesmo objetivo que o PNLD, o foco deste artigo é medir se o uso de materiais educacionais privados melhorou a qualidade da educação oferecida pelo município foco deste artigo.

\subsection{Sistema Brasileiro de Avaliação da Educação Básica - SAEB}

O SAEB consiste em um conjunto de avaliações externas em larga escala desenvolvidas pelo Ministério da Educação. Os dados estão acessíveis por escola e têm como objetivo avaliar a qualidade da educação oferecida pelo sistema educacional brasileiro. Esse sistema de avaliação foi criado em 2005 e é aplicado a cada dois anos por meio de testes cognitivos e questionários para estágios específicos do ensino básico. As evidências produzidas pelo SAEB permitem um amplo diagnóstico da educação básica oferecida no país, além da elaboração, monitoramento e aprimoramento das políticas educacionais. Na edição de 2017, a mais recente com dados disponíveis, mais de 5,4 milhões de estudantes participaram da avaliação de cerca de 73.000 escolas públicas e privadas de todo o Brasil. Nas provas aplicadas no quinto e nono ano do ensino fundamental, os alunos responderam a perguntas da língua portuguesa com foco na leitura e matemática na resolução de problemas (Fonte: http://portal.mec.gov.br/prova-brasil, acessado em 19 de novembro de 2019). Para os fins deste artigo, a nota escolar obtida para pesquisa é a proficiência média de seus alunos na língua portuguesa e matemática, padronizada para um indicador entre 0 e 10 (disponível no próprio site onde constam as notas).

\section{Pesquisa de Campo - Metodologia, coleta e análise de dados}

Esta sessão é reservada para a aplicação, em um estudo de caso, de conceitos de auditoria de desempenho com foco na efetividade da despesa pública. Inicia com a apresentação de uma metodologia para análise quantitativa de dados, seguida pela coleta e medição dos dados reais.

\subsection{Metodologia}

Um dos métodos mais populares para estimar o efeito de uma mudança de política é denominado diferença em diferenças - DD. Esta técnica estatística, derivada das análises de regressão múltipla ${ }^{19}$, é utilizada em econometria e em pesquisa quantitativa nas ciências sociais, e objetiva imitar um projeto de pesquisa experimental usando dados de estudos observacionais. O estimador de DD é usado quando há dados disponíveis antes e após o tratamento e quando a separação entre os grupos de tratamento e controle não foi realizada aleatoriamente. A diferença na média dos produtos antes e após a intervenção é calculada para cada grupo: tratado e não tratado; finalmente, a diferença entre essas duas diferenças é o impacto estimado. A Tabela 3 apresenta a técnica de forma esquemática.

- A-B e C-D representam até que ponto os grupos de controle e tratamento mudaram, respectivamente, entre o período antes e depois da intervenção;

- Como, por hipótese, o grupo de controle não foi impactado pelo projeto, a diferença (B-A) é resultado de outros fatores que afetam o indicador de impacto;

- Portanto, subtraindo B-A de D-C, espera-se que esses outros fatores se cancelem e, consequentemente, apenas o efeito do projeto permaneça.

\subsection{Coleta de dados}

Para realizar uma regressão baseada na técnica diferença em diferenças, as notas médias do SAEB foram obtidas de cada escola primária do município alvo, antes e após a adoção dos livros particulares.

A editora privada assinou contrato com o município de destino em dezembro de 2013 para fornecer seu sistema de ensino. O objetivo deste contrato, que vem sendo renovado a cada ano desde então, é: "a aquisição de livros integrados do sistema educacional $\mathrm{X}$, que visa atender aos alunos das séries $1^{\mathrm{a}}$ a $5^{\text {a }}$ do ensino fundamental municipal e melhorar o desempenho escolar" (destacado pelo autor).

Conforme o ISSAI 300, o princípio da efetividade diz respeito ao cumprimento dos objetivos estabelecidos e à obtenção

\footnotetext{
${ }^{19}$ Em estatística, a regressão é uma técnica que permite quantificar a relação entre os valores de uma variável dependente (indicador de impacto) e os valores de variáveis independentes específicas (variáveis explicativas).
} 
dos resultados pretendidos. Nesse sentido, foi realizada uma auditoria de desempenho para avaliar se a melhoria do desempenho escolar foi alcançada após 4 anos da adoção do material didático privado.

Para estabelecer a amostra a ser analisada, o critério foi selecionar, entre todas as escolas de ensino fundamental do município, apenas aquelas que tivessem ao menos 4 notas médias do SAEB entre os 7 testes de 2005 a 2017. No total, foram consideradas 57 escolas, compreendendo 370 notas de $5^{\text {a }}$ séries (ano em que os alunos fazem a prova Brasil). A partir de 2014, após o início do programa de ensino privado, as 38 escolas municipais que adotaram estes livros didáticos se transformaram no chamado grupo de tratamento. Com relação ao grupo de controle, se todas as escolas públicas de ensino fundamental do município tivessem adotado o método de ensino particular, seria muito difícil criar um grupo de controle confiável; portanto, nenhuma avaliação de impacto poderia ter sido realizada. Em vez disso, 3 das 41 escolas municipais de ensino fundamental e todas as 16 escolas de ensino fundamental administradas pelo Estado não utilizaram o material de aprendizagem do editor privado durante o período da pesquisa; portanto, essas escolas são o grupo de controle. É importante mencionar que nos dois grupos: tratamento e controle, as escolas variam em tamanho e número de alunos; portanto, essas características não interferem na análise. A Tabela 4 mostra os dados ${ }^{20}$ de todas as escolas estudadas para o cálculo da diferença nas diferenças.

\subsection{Medição de dados}

Para medir o impacto do material didático particular nas notas médias da escola, usando os testes SAEB, este artigo realizou a técnica da diferença de diferenças usando o software Microsoft Excel. O teste de diferença de diferenças, como mencionado anteriormente, é uma variação da análise de regressão múltipla. O que difere é que a metodologia Diferença-em-diferenças possui a chamada linha de base, ou seja, há informação dos grupos de tratamento e controle antes e depois do tratamento (neste caso, a adoção dos livros particulares a partir de 2014 para algumas das escolas do município alvo). Para os fins deste artigo, o cálculo da diferença em diferenças apresentado aqui é uma versão simplificada; a versão formal, como regressão estatística, consta no Apêndice A.

A técnica DD começa com o esquema apresentado na Tabela 3, preenchido com as médias dos dados da Tabela 4. Os valores são apresentados na Tabela 5.

O resultado das diferenças, - 0,0168, significa que houve um impacto negativo nas notas escolares médias do SAEB decorrente da adoção de material didático que não o fornecido pelo Governo Federal.

\section{Constatações}

O uso da técnica de avaliação de impacto denominada diferença em diferenças revelou que, no município-alvo, as escolas que adotaram método de ensino de editora privada tiveram, em média e após 4 anos do projeto, uma nota 0,0168 pontos menor do que as escolas que permaneceram usando o material didático fornecido pelo governo federal.

A decisão de adotar material didático privado é do governo municipal eleito; no entanto, este deve prestar contas à sociedade sobre suas escolhas. Nesse sentido, uma auditoria de desempenho focada no princípio da efetividade auxilia a avaliar se a escolha feita alcançou seus objetivos, uma vez que o município em questão possui demandas não atendidas na área da educação básica (vagas em creches, por exemplo), e os recursos disponíveis são limitados.

Segundo informações públicas recuperadas do sistema Licitacon Cidadã ${ }^{21}$, o custo do material privado no período analisado - 2014 a 2017 - foi de cerca de R \$ 16,6 milhões (R \$ 4,1 milhões por ano), ou seja: para o investimento realizado pelo município, obteve-se um decréscimo médio, no teste SAEB, de 0,0168 pontos.

Os gráficos a seguir permitem uma melhor visualização do impacto das notas ao longo dos anos. O gráfico 1 mostra que as notas médias do grupo de tratamento apresentam boa evolução ao longo dos anos / testes SAEB. No entanto, visualmente o grupo de controle apresenta evolução semelhante, demonstrando que não houve melhora devido à adoção do material didático fornecido pelo editor privado.

O gráfico 2, por sua vez, mostra a evolução das notas médias ao longo dos anos. É possível observar que o grupo de tratamento apresenta uma evolução maior entre os testes do SAEB de 2013 e 2015. No entanto, esse comportamento de notas não se mantém entre 2015 e 2017; consequentemente, não houve impacto positivo pela adoção do material didático privado.

Space for better visualization

\footnotetext{
${ }^{20}$ A nota média padronizada obtida nos testes do SAEB realizados nos anos de 2005, 2007, 2009, 2011, 2013, 2015 e 2017 (Fonte: http://idebescola.inep.gov.br/ideb/consulta-publica).

${ }^{21}$ O LicitaCon é um sistema informatizado desenvolvido pelo Tribunal de Contas do RS para controlar e monitorar as licitações e contratos administrativos assinados por todos os órgãos estaduais e municipais do estado do Rio Grande do Sul. A versão Cidadão, acessada para este artigo, está acessível em http://www1.tce.rs.gov.br/aplicprod/f?p=50500:1 .
} 


\section{Conclusões}

Este artigo analisou o impacto resultante da adoção de livros didáticos privados pela rede pública de escolas de um município brasileiro. Baseia-se em uma auditoria de desempenho focada no princípio da efetividade que aplicou uma técnica de avaliação denominada diferença em diferenças aos dados do Sistema Brasileiro de Avaliação da Educação Básica. O resultado da avaliação revelou que houve um impacto negativo de 0,0168 pontos nas notas médias do ensino fundamental, embora o material didático custe mais de $\mathrm{R} \$ 4$ milhões por ano para o município.

Pesquisas realizadas em 2018 no Brasil e no exterior constataram que as Instituições Superiores de Auditoria raramente realizam Auditorias de Desempenho com foco no princípio da efetividade. Espera-se que a partir da publicação deste artigo, auditorias que avaliem os impactos na população resultantes do uso de dinheiro público comecem a se tornar mais frequentes.

\section{Copyrights}

Copyright for this article is retained by the author(s), with first publication rights granted to the journal.

This is an open-access article distributed under the terms and conditions of the Creative Commons Attribution license which permits unrestricted use, distribution, and reproduction in any medium, provided the original work is properly cited. 